\title{
Ultra-processed food advertisements dominate the food advertising landscape in two Stockholm areas with low vs high socioeconomic status. Is it time for regulatory action?
}

Petter Fagerberg ${ }^{1 *}$ (D) Billy Langlet ${ }^{1}$, Aleksandra Oravsky ${ }^{1}$, Johanna Sandborg ${ }^{1,2}$, Marie Löf ${ }^{1,2}$ and loannis loakimidis ${ }^{1}$

\begin{abstract}
Background: Ultra-processed food consumption is a risk factor for obesity and has a negative environmental impact. Food companies spend billions of dollars on advertisements each year to increase the consumption of ultra-processed food. In Australia, USA, and New Zealand, most food advertisements around schools and in train stations promote ultra-processed food, but no similar studies have been conducted in Sweden. The aim of this study was to explore the proportion of ultra-processed food advertisements in two districts of Stockholm, Sweden with low vs. high socioeconomic status (SES).

Methods: Two independent researchers (per area) mapped all advertisements, including storefronts, in two Stockholm districts. During consecutive days, all advertisements were photographed in Skärholmen (low SES district), and Östermalmstorg (high SES district), on the streets inside and outside the subway stations, as well as inside and outside of local shopping malls. Advertisements promoting food products were identified and a trained dietician categorized whether they promoted ultra-processed foods. Chi-Square test was conducted to test for differences in the proportion of ultra-processed food advertisements between the two study areas.

Results: In total, 4092 advertisements were photographed in Skärholmen $(n=1935)$ and Östermalm $(n=2157)$. $32.8 \%$ of all advertisements promoted food, while $65.4 \%$ of food advertisements promoted ultra-processed foods. A significantly higher proportion of ultra-processed food advertisements out of total food advertisements was identified in the low SES area, irrespective of the researcher taking the pictures $(74.6 \%$ vs. $61.8 \%, p<0.001$ and $70.4 \%$ vs. $54.8 \%, p=0.001$ ). There was no significant difference in the proportion of food advertisements out of total advertisements between the two areas.

Conclusions: This study provides initial evidence about the scale and the differences in exposure to food advertisements across areas in Stockholm. The observed high proportion of ultra-processed food advertisements is concerning and is in sharp contrast to the Swedish dietary guidelines that recommend reduced consumption of such foods. Based on our results, residents in low SES areas might be more exposed to ultra-processed food advertisements than those in high SES areas in Stockholm. If such findings are confirmed in additional areas, they should be considered during the deployment of food advertisement regulatory actions.

(Continued on next page)
\end{abstract}

\footnotetext{
* Correspondence: petter.fagerberg@ki.se

${ }^{1}$ Innovative Use of Mobile Phones to Promote Physical Activity and Nutrition Across the Lifespan (the IMPACT) Research Group, Department of Biosciences and Nutrition, Karolinska Institutet, 14152 Stockholm, Sweden

Full list of author information is available at the end of the article
}

(c) The Author(s). 2019 Open Access This article is distributed under the terms of the Creative Commons Attribution 4.0 International License (http://creativecommons.org/licenses/by/4.0/), which permits unrestricted use, distribution, and reproduction in any medium, provided you give appropriate credit to the original author(s) and the source, provide a link to the Creative Commons license, and indicate if changes were made. The Creative Commons Public Domain Dedication waiver (http://creativecommons.org/publicdomain/zero/1.0/) applies to the data made available in this article, unless otherwise stated. 
(Continued from previous page)

Keywords: Outdoor advertising, Food advertising, Obesity, Ultra-processed food, Sugary drinks, Sugar, Sweetened beverages (SSB), Discretionary food, Fast food, Sustainability

\section{Introduction}

Today, obesity is one of the greatest public health threats in the world. In fact, obesity is associated with early death [1], type 2 diabetes [2], coronary artery disease [2], cancer [3] and depression [4], while the global economic burden of obesity has been estimated to be equivalent to that of smoking or armed violence, war, and terrorism added together [5]. Furthermore, the public health threat of obesity is growing, as its global prevalence has been steadily increasing from 3.2 and $6.4 \%$ in 1975, among men and women respectively, to 10.8 and $14.9 \%$ in 2014 [6]. This observation indicates that the problem might further worsen in the coming decades, if the trend continues.

The main cause of obesity is overconsumption of energy from foods and drinks relative to energy needs [7, 8]. A food type that has been shown to promote overconsumption of energy and subsequent weight gain is ultraprocessed foods (i.e. fast foods such as sugary drinks, junk foods and convenience foods). Indeed, recent epidemiological studies have linked ultra-processed foods to both weight gain and increased obesity prevalence [9]. In addition, the affordability of sugary drinks has been suggested to be the major driver of increased sugary drink purchase and consumption, which in turn is associated with higher levels of obesity prevalence [10]. Interestingly, the results of a recent randomized crossover trial, in a tightly controlled metabolic ward setting, strongly support that this relationship is causal, i.e. consumption of ultraprocessed foods results in higher energy intake, subsequently leading to increases in body weight [11].

Furthermore, changes in the global food system have been associated with the ongoing climate crisis [12], with ultraprocessed foods being identified as one of the most important diet-related environmental footprints [13]. Additionally, commercial actors, i.e. producers of ultra-processed foods, market their products aggressively and interfere with implementation of policies and regulations for the improvement of public and planetary health [12, 14].

In order to regulate the promotion of food and beverages, the International Chamber of Commerce (ICC) has provided a responsible communications framework, stating that "marketing communications should not undermine the importance of healthy lifestyles" and "claims should be conveyed consistent with the nature and scope of the evidence, providing the consumer with supportable information" [15]. Furthermore, in the advertising and marketing communications code [16], ICC states that "Information provided with the product should include proper directions for use and full instructions covering health and safety aspects whenever necessary. Such health and safety warnings should be made clear by the use of pictures, sound, text or a combination of these". However, currently, no such information exists on ultraprocessed food packaging (i.e. that consumption increases the risk for obesity and related diseases), even though ultra-processed food producers claim that they adhere to this framework, i.e. [17].

In Sweden, approximately half of the population is now overweight or obese, following the global trend, and localized obesity prevalence differences are not uncommon [18]. In the capital itself, Stockholm, similar regional/neighborhood differences in obesity prevalence have been observed $[19,20]$. Among 4-year-old children (born 2013), the prevalence of overweight and obesity ranges from $6.5-17.4 \%$ in different areas of Stockholm [19]. For example, in Skärholmen, an area with a high percentage of children belonging to households with non-Western background and low buying power, 14.3\% of 4-year-old children born 2013 were overweight or obese 2017. On the other hand, Östermalm, an area with a high percentage of children belonging to households with Swedish background and high buying power, only $7.3 \%$ of the 4-year-old children were overweight or obese 2017. In fact, the buying power of children's households has a strong negative correlation with obesity rates across the Stockholm region [19]. Similarly, among adults aged $18-64$ years, only $5.9 \%$ were obese in Östermalm 2015 vs. $18.2 \%$ in Skärholmen [20].

A potential cause of the observed regional differences (globally and in Sweden) might be different rates of exposure and availability of food and beverage advertisements. However, across the literature, most studies have been conducted on television advertising, with only a limited amount of studies done on outdoor advertisements. Taken together [21-29], the literature on outdoor food advertisements suggests that most food ads promote "unhealthy" foods, such as sugary beverages and fast foods (i.e. ultra-processed foods). Additionally, disadvantaged groups of residents seem to be targeted more heavily than others, potentially affecting their food purchasing habits.

Unfortunately, no studies on outdoor food advertisements have been conducted in Sweden and only one study has been conducted in the European context (Newcastle UK) [29]. Furthermore, no studies have examined potential differences in outdoor food advertisement exposure in areas of low and high socioeconomic status in Sweden. 
Therefore, the aim of this study was to explore the proportion of advertisements directly related to ultraprocessed foods (including sugary drinks and fast foods) in two areas of Stockholm, Sweden; 1) Skärholmen, an area with relatively high obesity prevalence and low socioeconomic status, and 2) Östermalm, an area with relatively low obesity prevalence and high socio-economic status. This study is an important addition to the food advertising literature since risk factors for diseases have been shown to differ both between and within countries $[8,30]$ and no comparable study has been conducted in Sweden.

\section{Methods}

\section{Study design}

A cross-sectional study design was used to examine the advertisements in the two included areas.

\section{Setting}

The study took place in Skärholmen and Östermalm, two districts located in Stockholm municipality (see Fig. 1) that is part of Stockholm county, Sweden. These areas represent low and high socio-economic status areas as

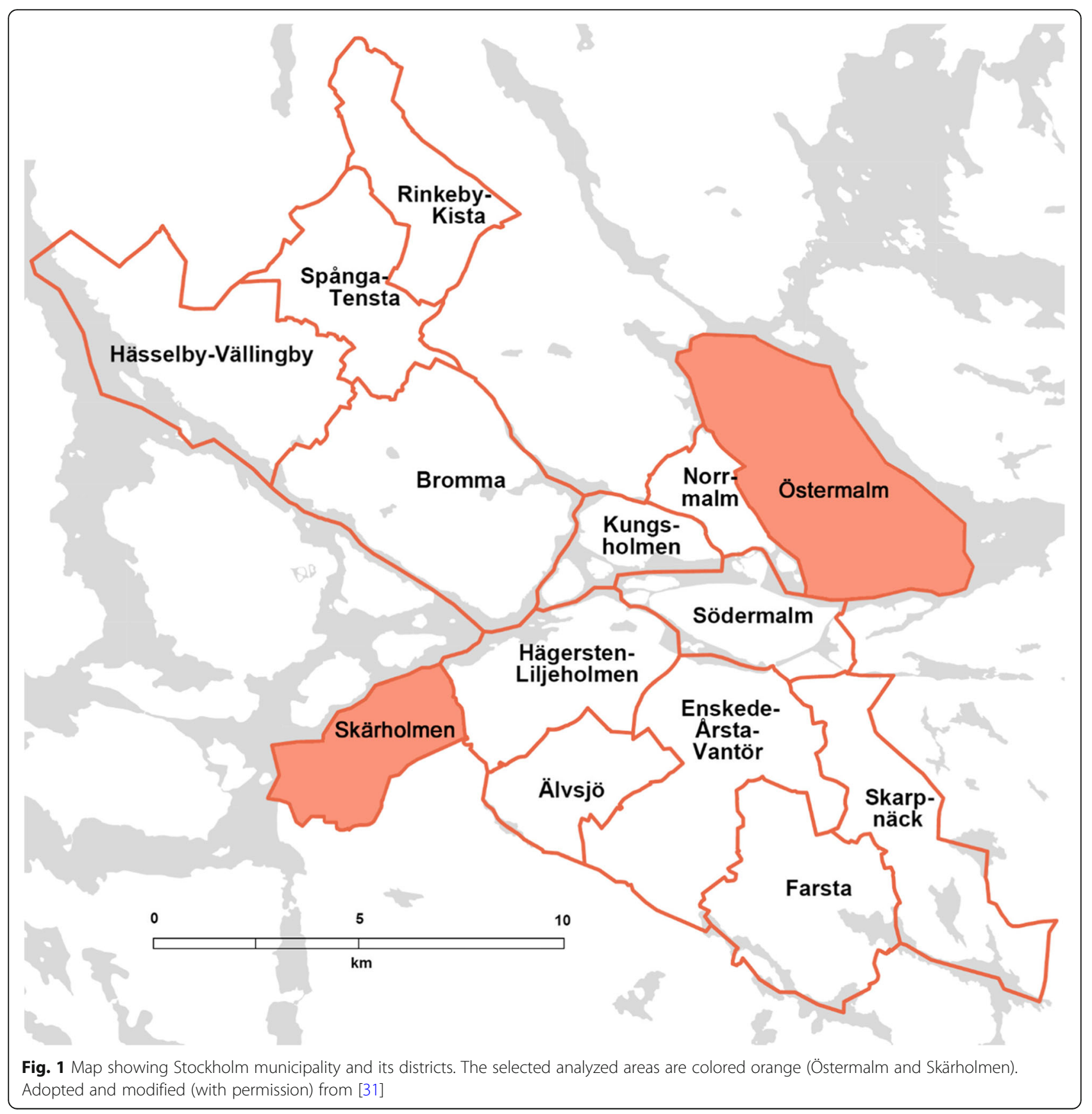


well as areas with disadvantaged vs. advantaged residents, respectively.

More specifically, a higher proportion of residents in Skärholmen are foreign born or born in Sweden with both parents born abroad ( $70 \%$ vs. $22 \%$ ), unemployed (6\% vs. $1.5 \%)$, uses sickness cash benefit and disability pension ( $26 \%$ vs. $10 \%$ ) compared to Östermalm. At the same time, a lower proportion of residents in Skärholmen vs. Östermalm have tertiary education ( $38 \%$ vs. $72 \%$ ) and the mean income is approximately half of the mean income in Östermalm (256.800 SEK/year vs. 505.500 SEK/year) [19, 31].

\section{Inclusion criteria}

The two areas were selected based on the local reported overweight and obesity prevalence $[19,31]$ and the fact that both areas have a subway station that is in close proximity to a shopping mall (within $100 \mathrm{~m}$ distance), thus making them reasonably comparable in advertisement exposure potential in these settings [32, 33].

\section{Data collection procedure}

On Wednesday 30th of May 2018 (Day 1, starting at $11.00 \mathrm{CET}$ ), two independent researchers (researcher 1 and researcher 2) travelled to Skärholmen, and on the next day, 1st of June 2018 (Day 2, also starting 11.00 $\mathrm{CET}$ ), researcher 1 and another independent researcher (researcher 3) travelled to Östermalmstorg to conduct the advertisement documentation process.

On day 1, all advertisements (including storefronts) in the subway station Skärholmen (including all advertisements $50 \mathrm{~m}$ to the left and right on the streets outside each of the entrances to the subway station) were documented by both researcher 1 and 2 . Thereafter, all advertisements inside the shopping mall "SKHLM" (located within $100 \mathrm{~m}$ proximity to Skärholmen subway station) were documented as well as all advertisements on the streets surrounding the shopping mall.

On day 2, the same procedure was repeated by researcher 1 and 3 in the subway station Östermalmstorg, the streets outside of the entrances to the subway station as well as inside and outside the shopping mall "Sturegallerian" (located within $100 \mathrm{~m}$ proximity to Östermalmstorg subway station).

We defined an advertisement as something that is shown or presented to the public to help sell a product or to make an announcement. If several advertisements were placed in a store window for promotion purposes, one picture including all products/advertisements seen in each store window was taken. If several advertisements were included on one poster (i.e. advertisements for discounted food products outside of supermarkets), then one picture per poster was taken. For rotating billboards, all advertisements shown within one complete rotation were recorded. No pictures of flyers or brochures were taken, neither were advertisements inside/ outside moving vehicles (i.e. busses and subway trains). Similarly, advertisements placed inside stores were not recorded.

\section{Data collection equipment}

To enable documentation of advertisements, smartphones with built-in cameras were used. Researcher 1 used Apple iPhone 7, researcher 2 LG G3 and researcher 3 used LG G6. All pictures of advertisements were later exported to a personal computer and sorted into folders for each researcher and location.

\section{Advertisement categorization process}

To facilitate the categorization process, an in-house built Excel (Microsoft ${ }^{\circ}$ ) tool was used (see Fig. 2), randomly ordering picture links in separate Excel rows. Thus, all

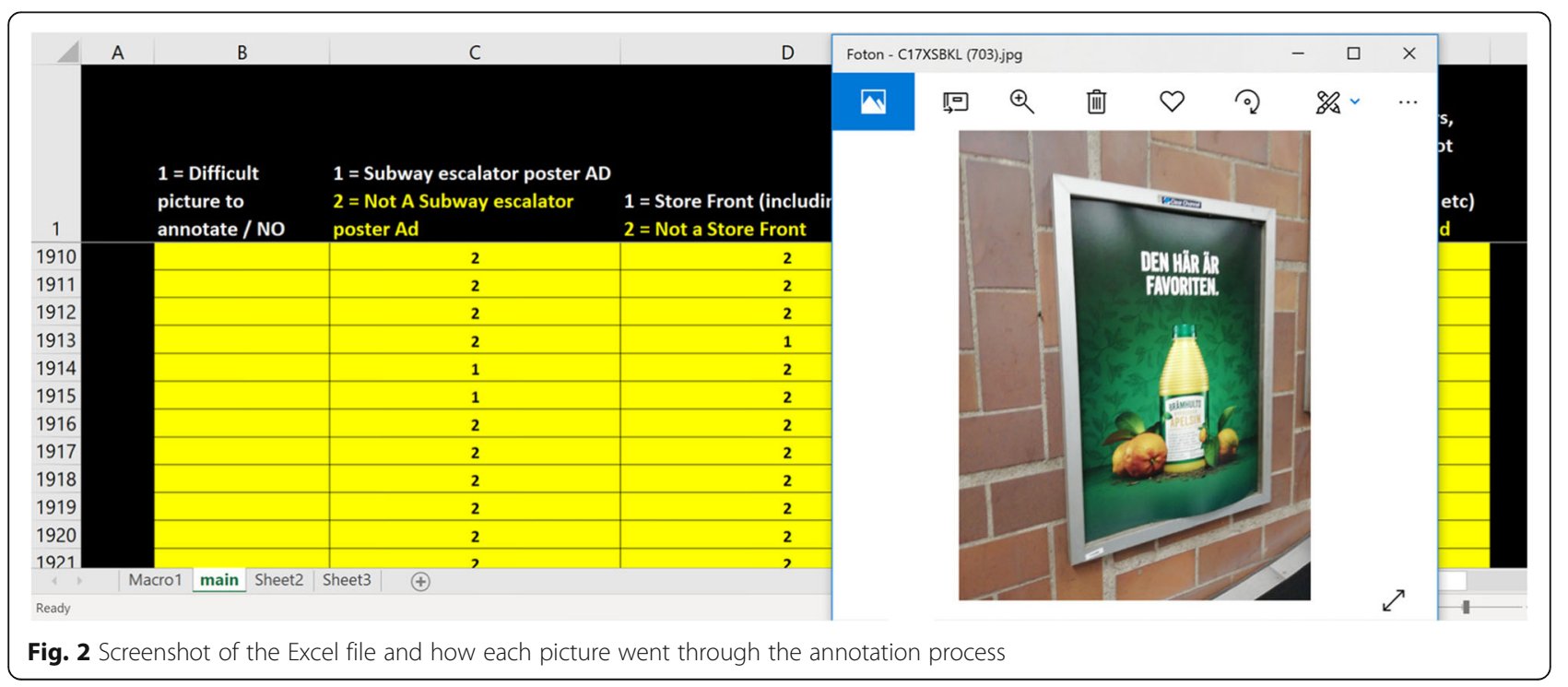


the collected pictures (taken by any researcher, during any of the two days) were accessed in random order. Each picture was marked by a hidden label (see black cells in column A in Fig. 2) encoding the identity of the researcher taking the picture and the originating area (Östermalm or Skärholmen). This enabled blinding of the "categorizer" (i.e., an independent, trained dietitian who did not participate in the data collection) about the location of each picture and the identity of the researcher who took it during the categorization process.

By clicking on a link in the Excel-file, the picture was loaded in the Microsoft Windows program "Photos" (see Fig. 2). Thereafter, the categorizer annotated each picture based on the following characteristics: 1) difficulty to annotate (see column B in Fig. 2), 2) being a subway escalator advertisement or not (see column $C$ in Fig. 2), 3) depicting a store front or not (see column D in Fig. 2), 4) being an advertisement promoting food or not (see column E in Fig. 2), 5) including a sugary drink or not, and lastly, 6) including fast food promotion or not (see column G in Fig. 2). The fast food label was given to typical Swedish fast food items, such as hamburgers, kebab, pizza, hot dog, ice cream, pastries, candy and similar items. Based on this categorization process, for example, a picture of an advertisement promoting a fast food item together with a sugary drink would receive both labels (i.e., "fast food" and "sugary drink"), thus contributing to both categories. A single trained dietician who didn't participate in the data collection categorized all the collected pictures. Finally, after the picture categorization process had been performed, another binary category was created (ultra-processed food) by adding the sum of "sugary drink" + "fast food" categories, in accordance with the Group 4 of the NOVA classification system [34], which includes soft drinks, sweet or savoury packaged snacks and reconstituted meat products (among others).

The categorization of subway escalator advertisements was added due to the special periodical, non-permanent nature of escalator advertisements in Stockholm (these change on weekly basis as stated by the advertisement company handling Stockholm subway advertising [35]). Indeed, the inclusion of such advertisements has the potential of significantly skewing the final analysis, due to the varied thematic of different advertising campaigns. Thus, the subway escalator advertisements were excluded from the final analysis. For example, during the data collection week, there was an ongoing advertising campaign specifically targeting the subway escalators in Östermalm. This campaign promoted a specific sugar sweetened juice $\left(\mathrm{MER}^{\circ}\right.$, owned by The Coca-Cola Company [36]) at $>100$ advertisement spots in Östermalm subway escalators. The results of the performed analysis including subway escalator advertisements can be found in "Additional file 1".

\section{Reliability of the categorization process}

To assess the reliability of ultra-processed food categorization, a random subset of the pictures belonging to the total picture dataset, consisting of 1000 pictures, was created and analyzed repeatedly by different categorizers. Thus, this sample was analyzed independently by the trained dietician and another trained researcher, to allow calculation of categorizer agreement (reliability).

\section{Statistical analysis}

Chi-Square test was conducted to test differences in ultraprocessed food proportions between the two study areas. $P<0.05$ was considered as the threshold for significance.

Cohen's Kappa (K) was used to evaluate inter-rater agreement. Kappa (K) value of $0-0.20$ was interpreted as "No agreement", 0.21-0.39 "Minimal agreement", 0.400.59 "Weak agreement", 0.60-0.79 "Moderate agreement", $0.80-0.90$ "Strong agreement", and above 0.90 as "Almost perfect agreement" [37].

SPSS 25 (IBM, Armonk, NY, USA) software [38] was used to test differences in proportions of advertisements, while descriptive statistics were calculated in Microsoft ${ }^{\circ}$ Excel.

\section{Results \\ Descriptive statistics}

In total, 4092 pictures of advertisements (ads) originating from Skärholmen $(n=1935)$ and Östermalm $(n=2157)$ were included in the final analysis. This dataset excludes subway escalator ads $(n=443)$ and pictures that were impossible to annotate (i.e. very blurry pictures, $n=8$ ). Out of the ads included in the final dataset, 1341 pictures (32.8\% of total ads) were ads promoting food products (33.1\% in Skärholmen vs. $32.5 \%$ in Östermalm), while 877 pictures (65.4\% of all food ads) were of ads promoting ultra-processed food products (i.e. sugary drinks, hamburgers, hot dogs, kebab, candy, ice cream etc.). More specifically, in Skärholmen, 466 pictures (73\% of total food ads) were ads promoting ultra-processed foods vs. 411 (59\% of total food ads) in Östermalm (See Fig. 3).

\section{Test of ad proportions}

There was no significant difference between Skärholmen and Östermalm in proportion of food ads out of total ads (Researcher 1: $34.9 \%$ vs. $35.1 \%, p=0.924, \chi^{2}=0.009$; Researcher $2+3: 31.1 \%$ vs. $29.9 \%, p=0.555, x^{2}=0.348$ respectively). However, Skärholmen had a significantly higher proportion of ads promoting ultra-processed food out of total food ads (Researcher 1: 74.6\% vs. 61.8\%, $p<$ 0.001, $\chi^{2}=13.869$; Researcher $2+3: 70.4 \%$ vs. $54.8 \%, p=$ $\left.0.001, \chi^{2}=15.675\right)$. More detailed data of the ads photographed in both areas are presented in Table 1.

The observed differences in the proportion of ultraprocessed food ads between the two areas were still present 


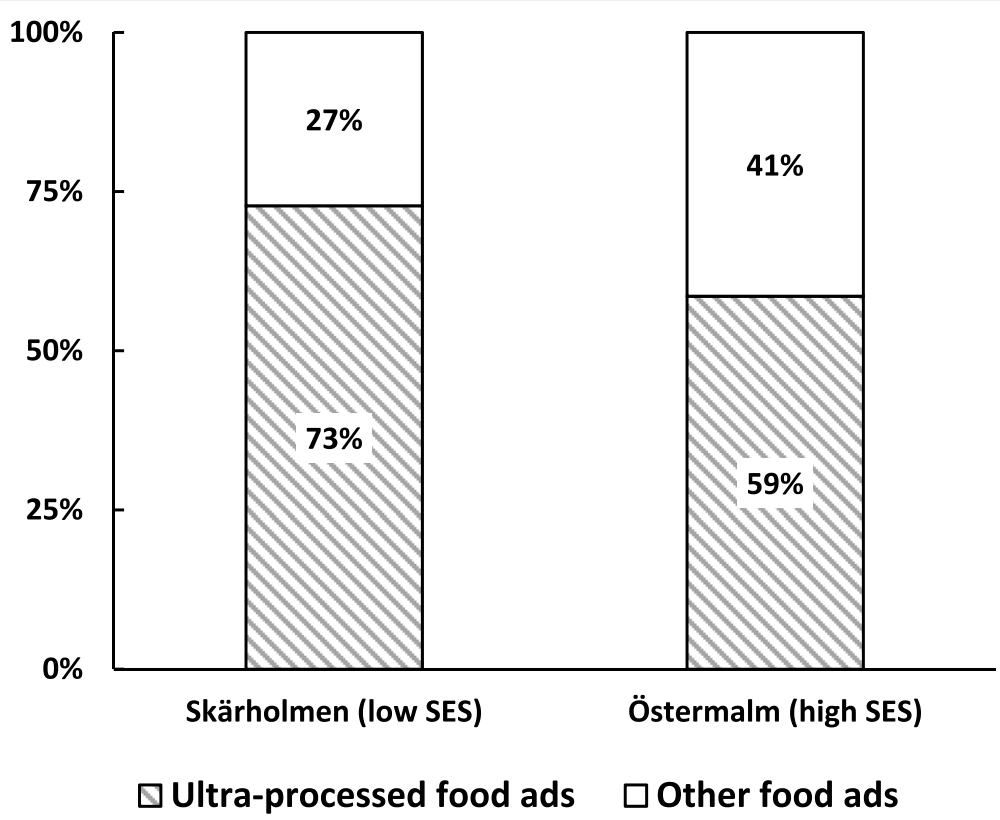

Fig. 3 Proportion of ultra-processed food advertisement out of total food advertisements in the two chosen areas of Stockholm (Skärholmen and Östermalm). Advertisements in subway escalators are excluded. SES = socio-economic status, ads = advertisements

when including subway escalator ads in both analyses [see Additional file 1]. The observed difference in ultra-processed food ads could be explained by a higher proportion of fast food ads out of total food ads in Skärholmen (Researcher 1: $65.4 \%$ vs. $48.8 \%, p=0.000, \chi^{2}=20.402$; Researcher $2+3$ : $61.1 \%$ vs. $\left.36.4 \%, p<0.001, \chi^{2}=36.863\right)$, but not by differing proportions of sugary drink ads out of total food ads (Researcher 1: $30.7 \%$ vs. $28.1 \%, p=0.442, \chi^{2}=0.590$; Researcher $2+3: 29.1 \%$ vs. $\left.30.6 \%, p=0.700, \chi^{2}=0.149\right)$.

\section{Reliability of advertisement categorization}

There was "almost perfect agreement" between the two raters for the categorization of subway escalator advertisements out of total ads $(\kappa=0.958)$. "Strong agreement" was observed for the categorization of food advertisements out of total ads $(\kappa=0.899)$ and sugary drinks out of total food ads $(\kappa=0.803)$. Finally, there was "moderate agreement" for the categorization of ultra-processed food ads out of total food ads $(\kappa=0.695)$ and for fast food ads out of total food ads $(\kappa=0.772)$.

\section{Discussion}

This is the first study to examine outdoor food and ultra-processed food advertisements in Stockholm, Sweden and is the first attempt to investigate potential differences between two districts with low vs. high socioeconomic status in the municipality of Stockholm. The results suggest that a high proportion $(\sim 60-70 \%)$ of

Table 1 Overview of the advertisements recorded at the two locations

\begin{tabular}{|c|c|c|c|c|}
\hline & & Östermalm & Skärholmen & Both areas \\
\hline \multirow[t]{5}{*}{ R1 } & Total ads & 1072 & 1017 & 2089 \\
\hline & Food ads (\% of total ads) & $377(35 \%)$ & $355(35 \%)$ & $732(35 \%)$ \\
\hline & Ultra-processed food ads (\% of food ads) & $233(62 \%)$ & $265(75 \%)$ & $498(68 \%)$ \\
\hline & Fast food ads (\% of ultra-processed food ads) & $184(79 \%)$ & $232(88 \%)$ & $416(84 \%)$ \\
\hline & Sugary drink ads (\% of ultra-processed food ads) & $106(45 \%)$ & $109(41 \%)$ & $215(43 \%)$ \\
\hline \multirow[t]{5}{*}{$R 2+R 3$} & Total ads & 1085 & 918 & 2003 \\
\hline & Food ads (\% of total ads) & $324(30 \%)$ & $285(31 \%)$ & $609(30 \%)$ \\
\hline & Ultra-processed food ads (\% of food ads) & $178(55 \%)$ & $201(70 \%)$ & $379(62 \%)$ \\
\hline & Fast food ads (\% of ultra-processed food ads) & $118(66 \%)$ & $174(87 \%)$ & $292(77 \%)$ \\
\hline & Sugary drink ads (\% of ultra-processed food ads) & $99(56 \%)$ & $83(41 \%)$ & $182(48 \%)$ \\
\hline
\end{tabular}

$\mathrm{R} 1=$ pictures taken by Researcher 1, R2 + R3 = pictures taken by Researcher 2 and 3. Researcher 1 and Researcher 2 took pictures of advertisements on the same day in Skärholmen and Researcher 1 and Researcher 3 took pictures of advertisements in Östermalm on the next day 
food advertisements, in these areas, are promoting ultraprocessed foods and that disadvantaged districts may be more exposed to such advertisements than advantaged districts.

The high prevalence of ultra-processed food advertisements among the total food advertisements is in line with observations made in train stations on the Sydney metropolitan train network [25], subway lines in Bronx, US [22], around primary schools in Wollongong and Sydney, Australia [26], around schools in urban and rural regions in New Zealand [27] and around public and private elementary schools in Cuernavaca and Guad alajara, Mexico [28]. This should not come as a surprise, taking into consideration the total advertising budgets of major food companies. For example, the two biggest global companies in the market segment of sugary drinks, dedicated $>8$ billion US dollars on product promotion in 2018 alone [39, 40].

However, these observations raise public health concerns since ultra-processed foods have been shown to cause overconsumption of energy and weight gain in humans [11], thus increasing the long-term risk of obesity and related negative consequences [1-5]. These concerns are even identified and discussed in the annual reports of major food companies [39, 40]. Additionally, epidemiological studies suggest a link between ultra-processed foods and increased risk of cardiovascular, coronary heart and cerebrovascular diseases [41], cancer [42], and all-cause mortality independently of BMI [43], as well as contributing to a negative environmental footprint $[12,13]$.

Furthermore, the overwhelming proportion of ultraprocessed food ads observed in our study are incompatible with the national nutritional guidelines in Sweden (Nordic Nutrition Recommendations [44]), which recommend the reduction of ultra-processed foods intake, promoting increased intake of fruits, vegetables, berries, nuts, seeds, whole grains, fish and vegetable oils instead (see Fig. 4) [44].

This great disconnect between Swedish nutritional recommendations and actual food advertisements in the two analyzed areas is quite striking. These results, mirrored by the observations in other countries, indicate that the "self-regulatory system" of the food industry has probably been ineffective in their "attempt" to adhere to the framework for responsible food and beverage marketing communications, as described by the International Chamber of Commerce (ICC) [15]. As noted before [46], additional, externally enforced regulations of food and beverage advertisements might be needed in order to ensure the adherence of food companies to responsible food marketing. From the industry side, the global introduction of such regulations has been described as a potential risk to product sales and longterm profitability (e.g., $[39,40])$, while the involved companies have previously tried to undermine the role of

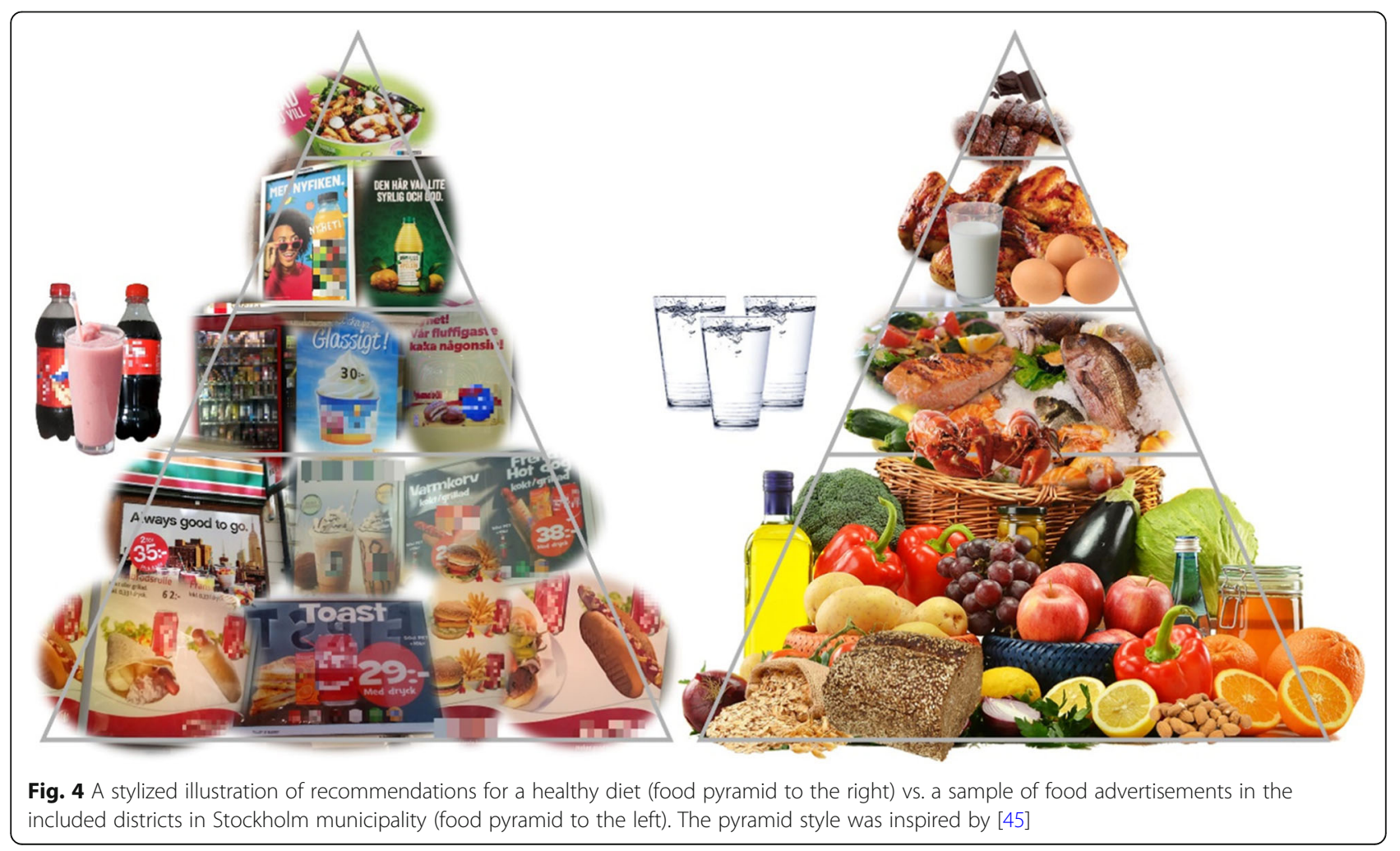


sugary drink consumption on national and global obesity prevalence [14]. Similarly, the food industry has also noted that additional labeling, warning requirements and/or increased taxes aimed at specific food products might reduce sales $[39,40]$. However, regulatory actions to reduce tobacco use, at least in Sweden, correlate with a reduction of the percentage of smokers from 27 to $11 \%$ (1989 vs. 2017 respectively) [47-49] and, currently, a similar public discussion for the regulation of gambling advertisements is ongoing [50]. Therefore, similar actions could potentially be useful to reduce ultra-processed food consumption and long-term obesity rates as well as reducing the climate impact from the production and distribution of these types of food products $[12,13]$.

Additionally, the observation of a higher proportion of ultra-processed food advertisement in the low vs. the high socioeconomic areas in Stockholm, points to an additional public health concern. In these areas, childhood obesity prevalence is several times larger (4\% vs. $0.4 \%$ ) in the district with low vs high socioeconomic status [19], and three times higher (18\% vs. 6\%) among adults [20]. At the same time, national data on both adolescents and adults have shown that more disadvantaged groups in Sweden have lower nutritional quality vs. more advantaged groups [51, 52], with higher percentages of unhealthy food advertising in disadvantaged areas potentially contributing to the issue. It is important to add that a connection between socioeconomic status in an area (and/ or living in neighborhoods with disadvantaged groups) and advertising of unhealthy food products have been observed before (i.e. in Australia [25], Bronx, New York, US [22], Los Angeles, Austin, New York and Philadelphia US [23], central Texas, US [24], Cuernavaca and Guadalajara, Mexico [28], and Wellington and Wairarapa New Zealand [27]), pointing toward the global character of the issue. Thus, it might be useful for novel food advertising regulations to acknowledge the socioeconomic and geographical aspects of the problem when they are deployed. In Sweden, in the domain of smoking, all the segments of the population (in regard to their educational level) seem to have been positively affected by the public anti-smoking regulations [53].

In the current study, the performed analysis of reliability showed "moderate agreement" for categorizing the variable ultra-processed food ads out of total food ads, highlighting the need for rigorous standards when categorizing food ads. In our case, we intentionally created a food advertisement protocol that removed the need of categorizing food advertisements on the recording spot (as previously done by others [26]). That allowed us to introduce another measure of unbiased advertisement categorization by "blinding" the trained dietician regarding the original location of each advertisement. Additionally, the selected protocol, based on recorded advertisement pictures, also facilitated better quality control of the categorizing process by independent researchers. For example, pictures categorized as ultra-processed food advertisements could be accessed by an independent researcher for re-evaluation. This process might be even more important in less diverse areas, i.e. when the difference in proportions of ultra-processed food is smaller between areas that are being compared. Additionally, our process allows for a more detailed analysis of the advertisements in the future (in accordance to previously suggested protocols in the Nordic countries [54]), i.e. restaurant ads, supermarket ads and specific brand logos etc. Finally, picture-based recording of advertisements may also accommodate an increased number of less trained researchers to record pictures, while the categorization of the advertisement is performed afterwards by dedicated research personnel. Thus, such a protocol is more scalable and could be considered in a "citizen science" data collection framework. Indeed, efforts for the collection of Big Data on behavioral and living environment parameters and their association with obesity prevalence are already ongoing [55]. The current study protocol, with minimal adaptations, could be a natural fit to such endeavors, providing data for use by public health authorities, as well as for the creation of educational opportunities through the organization of citizen science projects in collaboration with schools [56].

The subway escalator ad campaign observed in our study shows that the proportion of ultra-processed food ads can vary from one week to another in areas with subway stations, at least in Stockholm. In our study, this did not change the obtained results (i.e. proportion of ultra-processed food advertisements out of total food ads were still significantly higher in the district with low socioeconomic status vs. the one with high socioeconomic status [see Additional file 1]), but might be important if districts with more similar socioeconomic status are compared. In such case, repeated measures of ads would be needed to get a more representative view of the actual ultra-processed food advertisement exposure in the selected areas.

Our study has some limitations. To begin with, we conducted a cross-sectional analysis of food advertisements. Our results are therefore limited to the point in time of our data collection. Furthermore, we only included two out of fourteen available districts in Stockholm municipality. These districts were selected to represent socioeconomic extremes (i.e. relatively low average income vs. high, relatively low educational level vs. high etc.). It would be interesting to include more districts in Stockholm to evaluate if there are similar trends in ultra-processed food advertising in other areas as well. Adding to this point, we chose to analyze ads near the main subway station in each of the included districts, as well as the main local shopping mall. Future studies could therefore expand data collection to all subway stations and malls in an area to get a 
more complete picture of ad exposure. Additionally, ads were mapped during one week in the summer only, while a past report [25] have identified significant seasonal changes, with increased "unhealthy" food advertising during summer months, agreeing with food company reports that point to a seasonal variation of ultra-processed product sales $[39,40]$. Finally, similarly to the majority of this field, our study focused on a static quantification of food advertisement presence in certain geographical areas, without quantifying their exposure effects (elsewhere referred to as "viewership" [57]). In the future, use of eyetracking technology in the proposed protocol could further increase the analytical power. More concretely, level of attention on ultra-processed food advertisements vs. other food ads could be investigated.

\section{Conclusions}

Our study reveals that two districts of low vs high socioeconomic status in Stockholm municipality are being exposed to a high proportion of ultra-processed food advertisements out of total food ads. This observation is in sharp contrast to national dietary guidelines and regulatory action is suggested to reverse the current exposure to ultra-processed food ads. Additionally, our results indicate that residents in low socioeconomic status areas might be more exposed to ultra-processed food advertisements than residents in areas with high socioeconomic status in Stockholm. If such findings are confirmed in additional areas in Stockholm and across Sweden, they should be taken in consideration upon deployment of novel public health measures on food advertising. In the future, further optimizations in the data collection protocols might facilitate larger scale studies, describing the local food advertisement landscape across wider geographical areas.

\section{Supplementary information}

Supplementary information accompanies this paper at https://doi.org/10. 1186/s12889-019-8090-5.

Additional file 1. Proportion of ultra-processed food ads out of tota food ads between the two areas when including subway escalator ads.

\section{Abbreviations}

Ads: Advertisements; SES: Socioeconomic status

\section{Acknowledgements}

None.

\section{Authors' contributions}

Conceptualization, I.I., P.F., M.L., B.L.; Data curation, P.F., A.O., and J.S.; Formal analysis, P.F.; Funding acquisition, I.I., and M.L.; Investigation, P.F., J.S., and B.L.; Methodology, P.F., I.I., and M.L.; Project administration, I.I., and P.F.; Resources, I.I., and M.L.; Supervision, I.I., and M.L.; Visualization, P.F., I.I., B.L., M.L., and J.S.; Writing —original draft, P.F., I.I. and A.O.; Writing—review \& editing, P.F., I.I., M.L., A.O., B.L., and J.S. All authors read and approved the final manuscript.

\section{Funding}

The work leading to these results received funding from the European Community's ICT Programme under Grant Agreement No: 727688. The funding body had no role in the design of the study, collection, analysis, and interpretation of data or in writing the manuscript. Open access funding provided by Karolinska Institute.

\section{Availability of data and materials}

Data are available on a reasonable request.

Ethics approval and consent to participate

Not applicable.

\section{Consent for publication}

Not applicable.

\section{Competing interests}

The authors declare that they have no competing interests.

\section{Author details}

${ }^{1}$ Innovative Use of Mobile Phones to Promote Physical Activity and Nutrition Across the Lifespan (the IMPACT) Research Group, Department of Biosciences and Nutrition, Karolinska Institutet, 14152 Stockholm, Sweden. ${ }^{2}$ Department of Medical and Health Sciences, Linköping University, Linköping, Sweden.

Received: 9 October 2019 Accepted: 15 December 2019

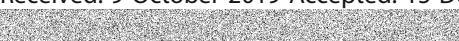

\section{References}

1. Bhaskaran K, dos-Santos-Silva I, Leon DA, Douglas IJ, Smeeth L. Association of BMI with overall and cause-specific mortality: a population-based cohort study of 3.6 million adults in the UK. Lancet Diabetes Endocrinol. 2018;6: 944-53.

2. Riaz H, Khan MS, Siddiqi TJ, Usman MS, Shah N, Goyal A, et al. Association between obesity and cardiovascular outcomes: a systematic review and meta-analysis of Mendelian randomization studies. JAMA Netw Open. 2018; 1:e183788.

3. Bhaskaran K, Douglas I, Forbes H, dos-Santos-Silva I, Leon DA, Smeeth L. Body-mass index and risk of 22 specific cancers: a population-based cohort study of 5.24 million UK adults. Lancet. 2014:384:755-65.

4. Luppino FS, de Wit LM, Bouvy PF, Stijnen T, Cuijpers P, BWJH P, et al. Overweight, obesity, and depression: a systematic review and meta-analysis of longitudinal studies. Arch Gen Psychiatry. 2010;67:220-9.

5. How the world could better fight obesity | McKinsey. https://www.mckinsey. com/industries/healthcare-systems-and-services/our-insights/how-the-worldcould-better-fight-obesity. Accessed 17 May 2019.

6. NCD Risk Factor Collaboration (NCD-RisC). Trends in adult body-mass index in 200 countries from 1975 to 2014: a pooled analysis of 1698 population-based measurement studies with 19.2 million participants. Lancet. 2016;387:1377-96.

7. Hall KD, Sacks G, Chandramohan D, Chow CC, Wang YC, Gortmaker SL, et al Quantification of the effect of energy imbalance on bodyweight. Lancet. 2011;378:826-37.

8. Swinburn BA, Sacks G, Hall KD, McPherson K, Finegood DT, Moodie ML, et al. The global obesity pandemic: shaped by global drivers and local environments. Lancet. 2011;378:804-14.

9. Costa CS, Del-Ponte B, MCF A, Santos IS. Consumption of ultra-processed foods and body fat during childhood and adolescence: a systematic review. Public Health Nutr. 2018;21:148-59.

10. Ferretti F, Mariani M. Sugar-sweetened beverage affordability and the prevalence of overweight and obesity in a cross section of countries. Glob Health. 2019:15:30

11. Hall KD, Ayuketah A, Brychta R, Cai H, Cassimatis T, Chen KY, et al. Ultra-processed diets cause excess calorie intake and weight gain: an inpatient randomized controlled trial of ad libitum food intake. Cell Metab. 2019:30:67-77.

12. Swinburn BA, Kraak VI, Allender S, Atkins VJ, Baker PI, Bogard JR, et al. The global Syndemic of obesity, Undernutrition, and climate change: the lancet commission report. Lancet. 2019;393:791-846.

13. Hadjikakou M. Trimming the excess: environmental impacts of discretionary food consumption in Australia. Ecol Econ. 2017;131:119-28. 
14. Barlow P, Serôdio P, Ruskin G, McKee M, Stuckler D. Science organisations and Coca-Cola's 'war' with the public health community: insights from an internal industry document. J Epidemiol Commun Health. 2018;72:761-3.

15. Framework for Responsible Food and Beverage Marketing Communications 2012. ICC - International Chamber of Commerce. https:/iccwbo.org/ publication/framework-for-responsible-food-and-beverage-marketingcommunications-2012/. Accessed 17 May 2019.

16. Marketing \& advertising. ICC - International Chamber of Commerce. https:// iccwbo.org/global-issues-trends/responsible-business/marketing-advertising/. Accessed 17 May 2019.

17. Our Way Forward | 2016 Sustainability report. The Coca-Cola Company. https://www.coca-colacompany.com/stories/2016-our-way-forward. Accessed 11 Jul 2019.

18. Statistik om övervikt och fetma — Folkhälsomyndigheten. http://www. folkhalsomyndigheten.se/folkhalsorapportering-statistik/folkhalsansutveckling/halsa/overvikt-och-fetma/. Accessed 15 May 2019.

19. Barnhälsovårdsrapporter | Vårdgivarguiden. https://www.vardgivarguiden.se/ behandlingsstod/bvc/barnhalsovardsrapporter/. Accessed 17 May 2019.

20. Geografiska variationer i fetma i relation till matvanor och fysisk aktivitet. https://www.folkhalsoguiden.se/material/rapporter/geografiska-variationer-ifetma-i-relation-till-matvanor-och-fysisk-aktivitet/. Accessed 17 May 2019

21. Lesser LI, Zimmerman FJ, Cohen DA. Outdoor advertising, obesity, and soda consumption: a cross-sectional study. BMC Public Health. 2013;13:20.

22. Lucan SC, Maroko AR, Sanon OC, Schechter CB. Unhealthful food-andbeverage advertising in Subway stations: targeted marketing, vulnerable groups, dietary intake, and poor health. J Urban Health Bull N Y Acad Med. 2017;94:220-32.

23. Yancey AK, Cole BL, Brown R, Williams JD, Hillier A, Kline RS, et al. A crosssectional prevalence study of ethnically targeted and general audience outdoor obesity-related advertising. Milbank Q. 2009:87:155-84.

24. Herrera AL, Pasch KE. Targeting Hispanic adolescents with outdoor food \& beverage advertising around schools. Ethn Health. 2018;23:691-702.

25. Sainsbury E, Colagiuri S, Magnusson R. An audit of food and beverage advertising on the Sydney metropolitan train network: regulation and policy implications. BMC Public Health. 2017;17:490.

26. Kelly B, Cretikos M, Rogers K, King L. The commercial food landscape: outdoor food advertising around primary schools in Australia. Aust N Z J Public Health. 2008;32:522-8.

27. Maher A, Wilson N, Signal L. Advertising and availability of "obesogenic" foods around New Zealand secondary schools: a pilot study. N Z Med J. 2005;118:U1556

28. Barquera S, Hernández-Barrera L, Rothenberg SJ, Cifuentes E. The obesogenic environment around elementary schools: food and beverage marketing to children in two Mexican cities. BMC Public Health. 2018;18. https://doi.org/10.1186/s12889-018-5374-0.

29. Adams J, Ganiti E, White M. Socio-economic differences in outdoor food advertising in a city in northern England. Public Health Nutr. 2011;14:945-50.

30. GBD 2017 Risk Factor Collaborators. Global, regional, and national comparative risk assessment of 84 behavioural, environmental and occupational, and metabolic risks or clusters of risks for 195 countries and territories, 1990-2017: a systematic analysis for the Global Burden of Disease Study 2017. Lancet. 2018;392:1923-94.

31. Statistik Stockholm - Statistisk årsbok för Stockholm. http://statistik. stockholm.se/publikationer/statistisk-arsbok-foer-stockholm. Accessed 24 May 2019.

32. SKHLM Skärholmen Centrum. https://www.skhlm.se/. Accessed 24 May 2019.

33. Sturegallerian. Sturegallerian. https://www.sturegallerian.se/. Accessed 24 May 2019.

34. Monteiro CA, Cannon G, Moubarac JC, Levy RB, MLC L, Jaime PC. The UN decade of nutrition, the NOVA food classification and the trouble with ultraprocessing. Public Health Nutr. 2018;21:5-17.

35. Marknadsledande inom utomhusreklam. Clear Channel. https://www. clearchannel.se/. Accessed 19 Sep 2019.

36. MER ${ }^{\oplus}$ Äpple. https://www.coca-cola.se/brands/mer/mer\%2D\%2Dapple. Accessed 24 May 2019.

37. McHugh ML. Interrater reliability: the kappa statistic. Biochem Medica. 2012; 22:276-82.

38. SPSS Software. 2019. https://www.ibm.com//analytics/spss-statisticssoftware. Accessed 23 May 2019.

39. Annual \& Other Reports. The Coca-Cola Company. https://www.cocacolacompany.com/investors/archives-annual-other-reports. Accessed 17 May 2019.
40. Annual Reports and Proxy Information. PepsiCo, Inc Official Website http:// www.pepsico.com/investors/annual-reports-and-proxy-information. Accessed 17 May 2019.

41. Srour B, Fezeu LK, Kesse-Guyot E, Allès B, Méjean C, Andrianasolo RM, et al. Ultra-processed food intake and risk of cardiovascular disease: prospective cohort study (NutriNet-Santé). BMJ. 2019;365:11451.

42. Fiolet $T$, Srour B, Sellem L, Kesse-Guyot E, Allès B, Méjean C, et al. Consumption of ultra-processed foods and cancer risk: results from NutriNet-Santé prospective cohort. BMJ. 2018;360:k322.

43. Rico-Campà A, Martínez-González MA, Alvarez-Alvarez I, de D MR, de la F-AC, Gómez-Donoso C, et al. Association between consumption of ultraprocessed foods and all cause mortality: SUN prospective cohort study. BMJ. 2019;365:11949.

44. Nordic Nutrition Recommendations 2012. Nordiskt samarbete. doi:https:// doi.org/10.6027/Nord2014-002

45. Läkartidningen - Prevention av diabetes typ 2 med fysisk aktivitet och hälsosam mat. https://www.lakartidningen.se/Klinik-och-vetenskap/ Temaartikel/2018/02/Prevention-av-diabetes-typ-2-med-fysisk-aktivitet-ochhalsosam-mat/. Accessed 3 Jul 2019.

46. Galbraith-Emami S, Lobstein T. The impact of initiatives to limit the advertising of food and beverage products to children: a systematic review. Obes Rev. 2013:14(12):960-74.

47. Färre röker, fler snusar. Statistiska Centralbyrån. http://www.scb.se/hittastatistik/artiklar/2018/farre-roker-fler-snusar/. Accessed 3 Jul 2019.

48. skatteverket.se S. Historiska skattesatser på cigaretter, cigarrer och cigariller. https://www.skatteverket.se/foretagochorganisationer/skatter/punktskatter/ tobaksskatt/skattesatser/tidigareskattesatser.4.121b82f011a74172e5880001 770.html. Accessed 4 Jul 2019.

49. Riksdagsförvaltningen. Lag (2018:2088) om tobak och liknande produkter Svensk författningssamling 2018:2018:2088 t.o.m. SFS 2019:124 - Riksdagen. https://www.riksdagen.se/sv/dokument-lagar/dokument/svenskforfattningssamling/lag-20182088-om-tobak-och-liknande-produkter_sfs-201 8-2088. Accessed 11 Jul 2019.

50. Regeringskansliet R och. Utredning ska föreslå begränsningar av spelreklamen. Regeringskansliet. 2019. https://www.regeringen.se/ pressmeddelanden/2019/04/utredning-ska-foresla-begransningar-avspelreklamen/. Accessed 11 Jul 2019.

51. Livsmedelsverket. https://www.livsmedelsverket.se/matvanor-halsa\%2D\%2 Dmiljo/kostrad-och-matvanor/matvanor\%2D\%2D-undersokningar/ riksmaten-2010-11\%2D\%2D-vuxna. Accessed 2 Jul 2019.

52. Livsmedelsverket. https://www.livsmedelsverket.se/matvanor-halsa\%2D\%2 Dmiljo/kostrad-och-matvanor/matvanor\%2D\%2D-undersokningar/riksmatenungdom. Accessed 2 Jul 2019.

53. Tobaksrökning, daglig — Folkhälsomyndigheten. http://www folkhalsomyndigheten.se/folkhalsorapportering-statistik/folkhalsansutveckling/levnadsvanor/tobaksrokning-daglig/. Accessed 3 Jul 2019.

54. Monitoring food marketing to children: A joint Nordic monitoring protocol for marketing of foods and beverages high in fat, salt and sugar (HFSS) towards children and young people - Open Research Online. http://oro. open.ac.uk/55676/. Accessed 3 Oct 2019.

55. Vogel C, Zwolinsky S, Griffiths C, Hobbs M, Henderson E, Wilkins E. A Delphi study to build consensus on the definition and use of big data in obesity research. Int J Obes. 2005;2019.

56. BigO. https://bigoprogram.eu/. Accessed 21 Feb 2018.

57. McGillivray K, Latka M. Field E. World Transit Res: Audience Measurement for Transit Advertising; 2012. https://www.worldtransitresearch.info/research/4584.

\section{Publisher's Note}

Springer Nature remains neutral with regard to jurisdictional claims in published maps and institutional affiliations. 